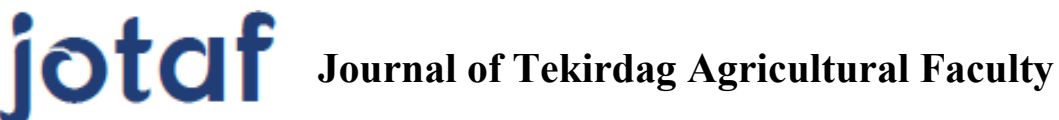

Tekirdağ Ziraat Fakültesi Dergisi

Mayis/May 2021, 18(2)

http://dergipark.gov.tr/jotaf

http://jotaf.nku.edu.tr/

\section{ARAŞTIRMA MAKALESI \\ RESEARCH ARTICLE \\ Stomatal Behaviors and Physiological Responses Affected by Iron Deficiency in Peach Plants Grafted onto Garnem and GF 677}

Garnem ve GF 677 üzerine Aşılı Şeftali Bitkilerinde Demir Eksikliğinden Etkilenen Stoma

Davranışları ve Fizyolojik Tepkiler

\section{Servet ARAS ${ }^{1 *}$, Hakan KELES ${ }^{2}$, Erhan BOZKURT ${ }^{3}$}

\begin{abstract}
Iron $(\mathrm{Fe})$ is a pivotal nutrient taking roles in respiration, photosynthesis and many plant metabolisms. Chlorosis caused by Fe deficiency generally occurs in high $\mathrm{pH}$ environments and many fruit trees including peach are known sensitive to iron starvation. Fe starvation declines leaf chlorophyll and carotenoid contents, supresses plant growth and declines photosynthetic capacity. Iron deficiency induces responses in plants and different stomatal behaviors and physiological alterations occur to sustain the increased iron uptake capacity of Fe-deficient plants. In this study, the effects of iron deficiency on stomatal morphology and leaf physiological responses in peach variety Rich May grafted onto Garnem and GF 677 rootstocks were investigated. Plants were exposed to Fe deficient conditions for 3 months. End of the experiment, many leaf and stomatal properties were evaluated. The highest decrease in plant growth (relative growth rates of shoot diameter and length) induced by Fe deficiency was found in Rich May grafted onto Garnem. SPAD and relative anthocyanin decreased by 52 and $70 \%$ in Fe deficient Rich May/Garnem grafting combination. Decreases in SPAD and relative anthocyanin values were lower with GF 677. In GF 677, LRWC decreased by $1.8 \%$ and membrane permeability increased by $10 \%$. Fe controlled stomatal behaviors in peach plants. Stomatal factors were found more sensitive to Fe deficiency in sensitive rootstock, Garnem. The increment in stomatal and pore areas leaded increase in stomatal conductance. The damage by Fe depletion was found higher in Garnem due to higher loss in SPAD, anthocyanin and increasing membrane permeability. Thus, GF 677 can be used in peach orchards under Fe deficiency conditions.
\end{abstract}

Keywords: Iron deficiency, Peach, Prunus, Rootstock, Stomata

\footnotetext{
1*Sorumlu Yazar/Corresponding Author: Servet ARAS, Yozgat Bozok University, Faculty of Agriculture, Department of Horticulture, Yozgat/Turkey. E-mail: servet.aras@yobu.edu.tr (D) OrcID: 0000-0002-0347-6552

${ }^{2}$ Hakan KELES, Adress, Yozgat Bozok University, Faculty of Agriculture, Department of Horticulture, Yozgat/Turkey. E-mail: hakan.keles@yobu.edu.tr OrcID: 0000-0002-8225-931X

${ }^{3}$ Erhan BOZKURT, Yozgat Bozok University, Faculty of Agriculture, Department of Horticulture, Yozgat/Turkey. E-mail: erhan.bozkurt@yobu.edu.tr iD OrcID: 0000-0002-1931-5454.

Atıf/Citation: ARAS S., KELES H.,BOZKURT E.2021. Stomatal Behaviors and Physiological Responses Affected by Iron Deficiency in Peach Plants Grafted onto Garnem and GF 677. Tekirdă̆ Ziraat Fakültesi Dergisi, 18 (2), 303-311.
}

CBu çalışma Tekirdağ Namık Kemal Üniversitesi tarafından Creative Commons Lisansı (https://creativecommons.org/licenses/by-nc/4.0/)

kapsamında yayınlanmıştır. Tekirdağ 2021 


\section{Özet}

Demir (Fe), solunum, fotosentez ve bitkilerin birçok metabolizmasında rol alan çok önemli bir besindir. Fe eksikliğinden kaynaklanan kloroz genellikle yüksek pH'lı ortamlarda ortaya çıkar ve şeftali dahil birçok meyve ağacının demir eksikliğine duyarlı olduğu bilinmektedir. Fe eksikliği, yaprak klorofil ve karotenoid içeriğini azaltır, bitki büyümesini baskılar ve fotosentetik kapasiteyi düşürür. Demir eksikliği bitkilerde tepkilere neden olur ve stomaya ait farklı davranışlar ve fizyolojik tepkiler Fe eksikliği olan bitkilerin artan demir alım kapasitesini sürdürmek için meydana gelmektedir. Bu çalışmada Garnem ve GF 677 anaçlarına aşılı Rich May şeftali çeşidinde demir eksikliğinin stoma morfolojisi ve yaprak fizyolojik tepkileri üzerine etkileri araştırılmıştır. Bitkiler, 3 ay süreyle mineral eksikliği olan koşullara maruz bırakılmıştır. Denemenin sonunda birçok yaprak ve stoma özelliği değerlendirilmiştir. Fe noksanlığında bitki büyümesinde (sürgün çapı ve uzunluğunun nispi büyüme oranlarında) en yüksek azalış Garnem üzerine aşılı şeftalilerde görülüp, bununla birlikte yine Garnem anacına aşılı şeftalilerde SPAD ve nispi antosiyanin $\% 52$ ve $\% 70$ oranlarında azalmıştır. GF 677 anacı üzerine aşılı olan şeftalilerde ise SPAD ve nispi antosiyanin değerlerinde daha düşük kayba sahip olmuştur. Garnem anacına aşıll çeşitlerde yaprak oransal su içeriği (YOSI) ve membran geçirgenliği Fe eksikliği ile artarken; GF 677'de YOSI \% 1,8 azalmış ve membran geçirgenliği \% 10 artmıştır. Fe şeftali bitkisinde stoma davranışlarını kontrol etmiştir. Hassas anaç olan Garnem'de stoma faktörleri Fe eksikliğine daha duyarlı bulunmuştur. Stoma ve gözenek alanlarındaki artış, stoma iletkenliğinde artışa neden olmuştur. Fe eksikliği zararı, SPAD ve antosiyaninde daha yüksek kayıplardan ve artan membran geçirgenliğinden dolayı Garnem'de daha yüksek bulunmuş̧ur. Bu yüzden GF 677, şeftali bahçelerinde Fe noksanlığı koşullarında kullanılabilir.

Anahtar Kelimeler: Demir eksikliği, Şeftali, Prunus, Anaç, Stoma 


\section{Introduction}

Iron $(\mathrm{Fe})$ is very important nutrient playing pivotal roles in respiration and photosynthesis (Kobayashi and Nishizawa, 2012). The symptom of Fe deficiency is leaf chlorosis which causes depression in plant growth (Gao et al., 2011). Chlorosis caused by Fe deficiency generally occurs in calcareous soils due to alkaline $\mathrm{pH}$ environments (Jiménez et al., 2011; Aras et al., 2018). Many fruit trees including peach are known sensitive to iron depletion (Eichert et al., 2010; Arikan et al., 2018). Fe starvation decreases leaf chlorophyll and carotenoid concentrations, depresses plant growth and declines photosynthetic capacity (Larbi et al., 2006; Fernández et al., 2008).

Iron is found predominantly in the form of $\mathrm{Fe}^{3+}$, however plants take up $\mathrm{Fe}$ most readily in the form of form of $\mathrm{Fe}^{2+}$. Therefore, $\mathrm{Fe}^{3+}$ must be reduced to $\mathrm{Fe}^{2+}$ with some mechanisms (García et al., 2018). Two mechanisms are known to iron transition; one mechanism in which Ferricchelate-reductase (FC-R) an enzyme playing key role in $\mathrm{Fe}^{3+}$ reduction to $\mathrm{Fe}^{2+}$ called as strategy I and the other one is called strategy II and it provides chelation to $\mathrm{Fe}$ availability (Donnini et al., 2009; Aras et al., 2018). Fruit trees utilize strategy I with the FC-R enzyme for Fe availability.

Stomata enable gas exchange between leaf and environment (Vráblová et al., 2018). Stress conditions induce changes in stomatal behaviors to adapt to environment. Changes in stomatal morphology play pivotal role in controlling gas exchange. Stomatal behavior can be evaluated by stomatal density, pore size and pore area (Gerardin et al., 2018). Kiani-Pouya et al. (2020) reported that salinity-tolerant barley plants reduced stomata density in order to decline water loss. In addition, many studies represented that drought stress causes decrease in stomatal aperture (Romero-Romero et al., 2018; Junlin et al., 2019). However, to our knowledge, a few studies are reporting the effects of Fe deficiency on stomatal properties in grafted peach.

The utilize of stress tolerant rootstocks represents a solution to alleviate stress damage (Aras and Eşitken, 2018). GF 677 rootstock is known Fe chlorosis-tolerant (Tagliavini and Rombola, 2001) and Garnem is sensitive to Fe chlorosis (Jiménez et al., 2008). Influence of Fe chlorosis on leaf anatomy was studied in previous experiments (Fernández et al., 2008; Eichert et al., 2010), in our study we focused on the stomatal properties under Fe starvation. Thus in the present experiment, we compared stomatal properties of peach plants grafted onto GF 677 and Garnem rootstocks under Fe deficiency conditions and the results were further evaluated by some plant growth traits and leaf physiological responses.

\section{Materials and Methods}

The experiment was performed in March of 2020 in a semi-controlled greenhouse (controlling climate factors) at the Yozgat Bozok University. One-year-old grafted plants from grafting combinations consisting of one peach cultivar; Rich May (Prunus persica Batsch) and two rootstocks; GF 677 (Prunus amygdalus x P. persica) and Garnem ( $P$. dulcis $\mathrm{x} P$. persica) were planted in $10 \mathrm{~L}$ pots containing perlite. The experiment was laid out in a randomized plot design with three replications involving five plants for each grafting combinations in each replication. Plants were treated with Hoagland solution (Hoagland and Arnon, 1950) for two months and, then were subjected to Fe deficient Hoagland solution for period of 3 months. In control groups Hoagland solution was used. Plants were fertigated once a week and $\mathrm{pH}$ of the solution was adjusted to 6.3. In the conclusion of the study, leaf and stomatal properties were evaluated.

\subsection{Morphological measurements}

Relative growth performances of different graft combinations under Fe depletion were determined in terms of shoot diameters and shoot length. Measurements of the shoot diameter and length were performed with a digital caliper (Mitutoyo) and ruler, respectively. The relative growth rates (RGR) were calculated using the equation (1) given below (Del Amor and Marcelis, 2003):

$\mathrm{RGR}=100 \times\left[\left(\ln \mathrm{Xt}_{2}-\ln X \mathrm{t}_{1}\right) /\left(\mathrm{t}_{2}-\mathrm{t}_{1}\right)\right]$

with $\mathrm{t}_{2}-\mathrm{t}_{1}=90$ days (duration of Fe depletion experiment), $\mathrm{Xt}_{2}=$ final shoot diameter and shoot length, $\mathrm{Xt}_{1}=$ initial shoot diameter and shoot length. 


\subsection{Physiological measurements}

Relative chlorophyll (SPAD) content was determined by a Minolta SPAD-502 chlorophyll meter (Minolta Camera Co, Ltd, Osaka, Japan). Stomatal conductivity and leaf temperature were conducted on the youngest fully expanded leaves on upper branches of the plants with leaf porometer (Li-COR). Relative anthocyanin content of the leaves was measured with an Anthocyanin Content Meter (ACM-200 plus).

Leaf relative water content (LRWC) was determined by the following equation (2) of Smart and Bingham (1974):

$$
\mathrm{LRWC}(\%)=[(\mathrm{FW}-\mathrm{DW}) /(\mathrm{TW}-\mathrm{DW})] \times 100
$$

with $\mathrm{FW}=$ fresh weight, $\mathrm{DW}=$ dry weight, $\mathrm{TW}=$ turgor weight

The procedure of membrane permeability (electrolyte leakage) based on Lutts et al. (1996) was utilized with an electrical conductivity (EC) meter. The leaf samples with $1 \mathrm{~cm}$ segments were imbibed in $10 \mathrm{~mL}$ of distilled water and incubated at room temperature $\left(25^{\circ} \mathrm{C}\right)$ on a shaker $(100 \mathrm{rpm})$ for $24 \mathrm{~h}$. Electrical conductivity of bathing solution $\left(\mathrm{EC}_{1}\right)$ was measured after incubation. The same samples were then placed in an autoclave at $120^{\circ} \mathrm{C}$ for 20 min and the second measurement $\left(\mathrm{EC}_{2}\right)$ was taken after cooling solution to room temperature. The electrolyte leakage was calculated as $\mathrm{EC}_{1} / \mathrm{EC}_{2}$ and expressed as percent.

\subsection{Stomatal properties}

Stomatal characteristics were measured on the abaxial surface of the leaves under light microscope. The samples of leaves taken from the treatments were stored in a 70\% ethanol solution. The leaf pieces were bleached in a $100 \%$ ethanol solution to observe stomatal morphology and placed on a slide and visualized with a light microscope (Olympus CX21) coupled to a digital camera (Kameram 5). Stomatal length, width, perimeter, pore length, width, perimeter and stomata density were measured. Stomata area and pore area were calculated with the following equation (3) (Zhu et al., 2019):

Stomata area $=(\pi * \mathrm{SL} * \mathrm{SW}) / 4$, Pore area $=(\pi * \mathrm{PL} * \mathrm{PW}) / 4$

with $\mathrm{SL}=$ stomatal length, $\mathrm{SW}=$ stomatal width, $\mathrm{PL}=$ pore length, $\mathrm{PW}=$ pore width

\subsection{Statistical analyses}

The statistical analyses were performed with the statistical software package SPSS, version 20.0. Data were subjected to two-way ANOVA and means were separated by the Duncan's test at a significance level of $\mathrm{P}<0.05$.

\section{Results and Discussion}

\subsection{Plant growth and physiological responses}

Iron deficiency significantly affected plant growth in grafted peach plants (Table 1). The highest decrease in plant growth by Fe deficiency was found in Rich May grafted onto Garnem. Under Fe deficiency conditions all plants in grafting combinations produced lower shoot RGR related to control plants. The higher decreases were recorded in Rich May/Garnem. Concerning shoot RGR in diameter and in length Rootstock Garnem resulted in 9 and $50 \%$ respectively decrease under Fe depletion. Alternatively decreases in shoot RGR in diameter and in length with GF 677 rootstock were 6 and 10\%, respectively.

Table 1. Effects of Fe deficiency on shoot growth in grafted peach plants

\begin{tabular}{cccc}
\hline Variety/Rootstock & Treatments & shoot RGR in diameter & shoot RGR in length \\
\hline \multirow{2}{*}{ Rich May/Garnem } & Control & $0.5587 \mathrm{a}$ & $0.8967 \mathrm{a}$ \\
& Fe deficient & $0.5049 \mathrm{~b}$ & $0.4418 \mathrm{~b}$ \\
\hline \multirow{2}{*}{ Rich May/GF 677 } & Control & $0.7015 \mathrm{a}$ & $0.6781 \mathrm{a}$ \\
& Fe deficient & $0.6543 \mathrm{~b}$ & $0.6107 \mathrm{~b}$ \\
\hline
\end{tabular}

Means separation within column by Duncan's multiple range test. $\mathrm{P}<0.05$ 
The physiological responses of peach leaves were also statistically influenced by Fe deficiency. SPAD values and relative anthocyanin content decreased by 52 and 70\% in Rich May/Garnem grafting combinations under Fe deficiency (Table 2). As in the case of shoot RGR the losses were lower in plants graftted onto GF 677. Alternatively stomatal conductance increased with rootstock Garnem whereas it decreased with rootstock GF 677 (Table 2).

The leaf temperature, membrane permeability and LRWC were also affected by rootstocks under Fe deficiency. The leaf temperature decreased by 3.0\% in Garnem while increased by 3.4\% in GF 677 (Table 3). Fe deficiency increased LRWC and membrane permeability increased in Garnem. In GF 677, LRWC decreased by $1.8 \%$ and membrane permeability increased $10 \%$ (Table 3 ).

Table 2. Effects of Fe deficiency on SPAD value, relative anthocyanin content and stomatal conductance in grafted peach plants

\begin{tabular}{lllll}
\hline Variety/Rootstock & Treatments & $\begin{array}{l}\text { SPAD } \\
\text { value }\end{array}$ & $\begin{array}{l}\text { Relative } \\
\text { anthocyanin value }\end{array}$ & $\begin{array}{l}\text { Stomatal conductance } \\
\left(\mathrm{mmol} \mathrm{m}^{-2} \mathrm{~s}^{-1}\right)\end{array}$ \\
\hline \multirow{2}{*}{ Rich May/Garnem } & Control & $48.03 \mathrm{a}$ & $13.4 \mathrm{a}$ & $111.4^{\mathrm{NS}}$ \\
& Fe deficient & $23.93 \mathrm{~b}$ & $3.96 \mathrm{~b}$ & 117.3 \\
\hline \multirow{2}{*}{ Rich May/GF 677 } & Control & $45.9 \mathrm{a}$ & $11.96 \mathrm{a}$ & $145.6 \mathrm{a}$ \\
& Fe deficient & $31.5 \mathrm{~b}$ & $6.56 \mathrm{~b}$ & $96.5 \mathrm{~b}$ \\
\hline
\end{tabular}

Means separation within column by Duncan's multiple range test. $\mathrm{P}<0.05$, NS: Non Significant

Table 3. Effects of Fe deficiency on leaf temperature, LRWC and membrane permeability in grafted peach

\begin{tabular}{lllll}
\multicolumn{5}{c}{ plants } \\
\hline Variety/Rootstock & Treatments & $\begin{array}{l}\text { Leaf temperature } \\
\left({ }^{\circ} \mathrm{C}\right)\end{array}$ & $\begin{array}{l}\text { LRWC } \\
(\%)\end{array}$ & $\begin{array}{l}\text { Membrane } \\
\text { permeability }(\%)\end{array}$ \\
\hline \multirow{2}{*}{ Rich May/Garnem } & Control & $33.03 \mathrm{a}$ & $86.44 \mathrm{~b}$ & $32.27 \mathrm{~b}$ \\
& Fe deficient & $32.03 \mathrm{~b}$ & $91.16 \mathrm{a}$ & $37.89 \mathrm{a}$ \\
\hline \multirow{2}{*}{ Rich May/GF 677 } & Control & $32.9 \mathrm{~b}$ & $86.50 \mathrm{a}$ & $40.16 \mathrm{~b}$ \\
& Fe deficient & $34.03 \mathrm{a}$ & $84.96 \mathrm{~b}$ & $44.07 \mathrm{a}$ \\
\hline
\end{tabular}

Means separation within column by Duncan's multiple range test. $\mathrm{P}<0.05$, NS: Non Significant

\subsection{Stomatal behaviors}

Stomatal morphology was affected by Fe deficiency results differed between rotstocks (Table 4 and Table 5). Peach plants grafted onto Garnem produced higher means of stomatal length, width and perimeter under Fe deficiency conditions. In Rich May grafted on GF 677, stomatal length increased by 3\% and stomatal width and perimeter decreased by 8.5 and 5.0\%, respectively. Fe deficient Garnem had lower stomatal density and higher stomatal area compared to control. In GF 677, stomatal density and area decreased under Fe deficiency.

In Rich May/GF 677 graft combination pore length, width, perimeter and area were tend to be decreased by Fe deficiency (Table 5). In Rich May/Garnem, pore width decreased while pore length, perimeter and area increased by Fe deficiency.

Table 4. Effects of Fe deficiency on stomatal properties in grafted peach plants

\begin{tabular}{|c|c|c|c|c|c|c|}
\hline Variety/Rootstock & Treatments & $\begin{array}{l}\text { Stomatal } \\
\text { length } \\
(\mu \mathrm{m})\end{array}$ & $\begin{array}{l}\text { Stomatal } \\
\text { width }(\mu \mathrm{m})\end{array}$ & $\begin{array}{l}\text { Stomatal } \\
\text { perimeter } \\
(\mu \mathrm{m})\end{array}$ & $\begin{array}{l}\text { Stomatal } \\
\text { density (no. } \\
\mathrm{mm}^{-2} \text { ) }\end{array}$ & $\begin{array}{l}\text { Stomatal } \\
\text { area }\left(\mu \mathrm{m}^{2}\right)\end{array}$ \\
\hline \multirow[t]{2}{*}{ Rich May/Garnem } & Control & $29.66 \mathrm{~b}$ & $22.66 \mathrm{~b}$ & $91.74 \mathrm{~b}$ & $372.0 \mathrm{a}$ & $530.1 \mathrm{~b}$ \\
\hline & Fe deficient & $32.5 \mathrm{a}$ & $23.9 \mathrm{a}$ & $98.56 \mathrm{a}$ & $340.3 \mathrm{~b}$ & $610.2 \mathrm{a}$ \\
\hline \multirow[t]{2}{*}{ Rich May/GF 677} & Control & $31.83 \mathrm{~b}$ & $25.43 \mathrm{a}$ & $98.66 \mathrm{a}$ & $293.3 \mathrm{a}$ & $636.5 \mathrm{a}$ \\
\hline & Fe deficient & $32.83 \mathrm{a}$ & $23.26 \mathrm{~b}$ & $93.83 \mathrm{~b}$ & $283.0 \mathrm{~b}$ & $601.3 \mathrm{~b}$ \\
\hline
\end{tabular}

Means separation within column by Duncan's multiple range test. $\mathrm{P}<0.05$ 
Table 5. Effects of Fe deficiency on pore properties in grafted peach plants

\begin{tabular}{llllll}
\hline Variety/Rootstock & Treatments & $\begin{array}{l}\text { Pore length } \\
(\mu \mathrm{m})\end{array}$ & $\begin{array}{l}\text { Pore width } \\
(\mu \mathrm{m})\end{array}$ & $\begin{array}{l}\text { Pore } \\
\text { perimeter } \\
(\mu \mathrm{m})\end{array}$ & $\begin{array}{l}\text { Pore area } \\
\left(\mu \mathrm{m}^{2}\right)\end{array}$ \\
\hline Rich May/Garnem & Control & $14.66 \mathrm{~b}$ & $7.3^{\mathrm{NS}}$ & $40.68^{\mathrm{NS}}$ & $84.04 \mathrm{~b}$ \\
& Fe deficient & $15.35 \mathrm{a}$ & 7.2 & 40.75 & $87.72 \mathrm{a}$ \\
\hline Rich May/GF 677 & Control & $17.46 \mathrm{a}$ & $8.03 \mathrm{a}$ & $48.06 \mathrm{a}$ & $110.71 \mathrm{a}$ \\
& Fe deficient & $16.30 \mathrm{~b}$ & $7.6 \mathrm{~b}$ & $45.30 \mathrm{~b}$ & $97.41 \mathrm{~b}$ \\
\hline
\end{tabular}

Means separation within column by Duncan's multiple range test. $\mathrm{P}<0.05$, NS: Non Significant

\section{Discussion}

Current experiment revealed that leaf chlorosis and necrosis were observed in both rootstocks under Fe deficiency conditions. The degree of the Fe chlorosis was found to be higher in Rich May/ Garnem than those in Rich May/ GF 677 graft combinations.

\subsection{Plant growth}

Retardation in plant growth has been reported in many fruit trees imposed to environmental stress factors (Yin et al., 2010; Aras and Eşitken, 2018). Gruber and Kosegarten (2002) stated that restriction in plant growth is a clear symptom of Fe deficient plants. Iron takes a key role in photosynthesis and electron transport system (Morales et al., 1990), thus depressed growth could be caused by decline in photosynthesis (not determined in the present study) due to Fe deficiency. In the present study, we evaluated plant growth in terms of RGR of shoot diameter and length. Relative growth rate is an important indicator of plant growth affected by net assimilation rate, leaf area, dry matter distribution are related to the characteristics of the rootstocks (Solari et al., 2006; Aras et al., 2019). Fe deficiency caused a remarkable decrease in the RGRs. The decline in the RGRs was more pronounced in Rich May/Garnem.

\subsection{Physiological responses}

Iron takes pivotal roles in function of chloroplast and the Fe deficiency leads to a decline in chlorophyll content (Valipour et al., 2020) and causes interveinal chlorosis (Molassiotis et al., 2006; Aras et al., 2018). SPAD value quantifies the relative chlorophyll content in the leaves and in our study SPAD decreased by Fe deficiency in both rootstocks. Djennane et al. (2011) reported that SPAD value decrease from 30.6 to 24.4 in pear genotypes under Fedepletion conditions. Decrease in SPAD was higher in Rich May/Garnem in our study. Similar to chlorophyll, relative anthocyanin content decreased under Fe deficiency. It has been reported that many nutrients including Fe take a role in anthocyanin biosynthesis (Shi et al., 2017). From this point of view it can be speculated that rootstock GF 677 has a reducing effect on losses in anthocyanin content compared to Garnem under Fe deficiency conditions.

Iron deficiency damaged cell membranes in peach plants determined by membrane permeability. The damage was higher in Garnem compared to GF 677. Increment in membrane permeability was reported in many environmental stress studies regarding salinity (Aras and Eşitken, 2018), drought (Bat et al., 2020). Here we report that under Fe deficient conditions cell membrane damage was lower in GF 677 than in Garnem.

Stomatal conductance is affected by environmental factors (Pouyafard et al., 2016) and was differently affected by Fe deficiency. The value increased in Garnem, while it decreased in GF 677 under Fe deficiency conditions. Sharma et al. (2016) reported that stomatal conductance increase in cauliflower under Fe deficiency. Alternatively Mattiello et al. (2015) stated that stomatal conductance decreased under zinc (Zn) deficiency. We suggest that Fe deprivation increased leaf transpiration thus promoted uptake of Fe from rhizosphere consequently led to decrease in leaf temperature and increase in LRWC in Rich May/Garnem.

\subsection{Stomatal behaviors}

Plants control stomatal morphology against stress factors (Demirbaş and Balkan, 2018). Decline in stomatal density and area is well reported under drought conditions (Romero-Romero et al., 2018; Junlin et al., 2019). However, there 
is no clear result on stomatal behaviors under Fe deficient conditions. In a previous experiment, stomatal pore area of peach leaves decreased by $49 \%$ under Fe deficiency conditions (Fernández et al., 2008). In the current study, we evaluated stomatal behaviors in terms of stomata (whole stomata) and pore (stomatal aperture). We found that stomatal density decreased by Fe deficiency in peach plants. However rootstock responses varied. Stomatal and pore areas increased in Garnem while the values decreased in GF 677 in Fe deficient conditions. While Fe deficiency give rise to stomatal perimeter when used Garnem, it did not affect pore perimeter. On the other hand with rootstock GF 677 both stomatal perimeter and pore perimeter declined under Fe deficiency. These results support the increment in stomatal conductance in Garnem and decline in stomatal conductance in GF 677. Mineral uptake by roots is provided by leaf transpiration (Alarcón et al., 1999) and we concluded that Garnem rootstock led to an increase in stomatal conductance and stomatal and pore area under Fe deficiency. GF 677 tolerated Fe deficiency and did not required high stomatal conductance and stomatal area. Ridolfi and Garrec (2000) stated that stomatal density increased in beech leaves under $\mathrm{Ca}$ and $\mathrm{Mg}$ conditions. Mattiello et al. (2015) reported that stomata density increased in maize leaves under $\mathrm{Zn}$ deficiency conditions. Stomatal density decreased by boron deficiency in Dittrichia viscosa plant (Stavrianakou et al., 2006).

Stomatal respond to signals under stress conditions and smaller stomata faster respond to signaling cues (Lawson and Matthews, 2020). In our study, decreases in stomatal perimeter and area in GF 677 suggest faster stomatal closure and decline in stomatal conductance.

\section{Conclusion}

Iron controlled stomatal behaviors in peach plant. Stomatal factors were found to be more sensitive to Fe deficiency in sensitive rootstock, Garnem. Moreover, increment in stomatal and pore areas led to an increase in stomatal conductance. Fe deficiency stimulated decrease in Chlorophyll and anthocyanin values and increase in leaf damage. The damage caused by Fe depletion was found to be higher in Garnem presumably due to higher losses in SPAD and anthocyanin values and increasing membrane permeability. This study offers evidences for a better understanding over detrimental influences of Fe-deficiency at the leaf level.

\section{Acknowledgement}

This study was supported by the grants from Yozgat Bozok University with Project Coordination Application and Research Center with 6602c-ZF/20-387 project number. 


\section{References}

Alarcón, A. L., Madrid, R., Egea, C., Guillén, I. (1999). Calcium deficiency provoked by the application of different forms and concentrations of $\mathrm{Ca} 2+$ to soil-less cultivated muskmelons. Scientia Horticulturae, 81(1): 89-102.

Aras, S., Eşitken, A. (2018). Physiological responses of cherry rootstocks to short term salinity. Erwerbs-Obstbau, 60: 161-164.

Aras, S., Arıkan, Ş., İpek, M., Eşitken, A., Pırlak, L., Dönmez, M. F., Turan, M. (2018). Plant growth promoting rhizobacteria enhanced leaf organic acids, FC-R activity and Fe nutrition of apple under lime soil conditions. Acta Physiologiae Plantarum, 40(6):120.

Aras, S., Eşitken, A., Karakurt, Y. (2019). Morphological and physiological responses and some WRKY genes expression in cherry rootstocks under salt stress. Spanish Journal of Agricultural Research, 17(4): 0806.

Arikan, Ş., Eşitken, A., İpek, M., Aras, S., Şahin, M., Pırlak, L., Dönmez, M. F., Turan, M. (2018). Effect of plant growth promoting rhizobacteria on Fe acquisition in peach (Prunus persica L) under calcareous soil conditions. Journal of Plant Nutrition, 41 (17): 2141 2150 .

Bat, M., Tunçtürk, R., Tunçtürk, M. (2020). Ekinezya (Echinacea purpurea L.) bitkisinde kuraklık stresi ve deniz yosunu uygulamalarının bazı fizyolojik parametreler üzerine etkisi. KSÜ Tarım ve Doğa Dergisi, 23(1): 99-107.

Del Amor, F., Marcelis, L. F. M. (2003). Regulation of nutrient uptake, water uptake and growth under calcium starvation and recovery. Journal of Horticultural Science and Biotechnology, 7: 343-349.

Demirbaş, S., Balkan, A. (2018). Tuz stresi koşullarında bazı tritikale çeşitlerinin hidrojen peroksit $\left(\mathrm{H}_{2} \mathrm{O}_{2}\right)$ ön uygulamasına tepkileri. Journal of Tekirdag Agricultural Faculty, 15(2): 5-13.

Djennane, S., Cesbron, C., Sourice, S., Cournol, R., Dupuis, F., Eychenne, M., Loridon, K., Chevreau, E. (2011). Iron homeostasis and fire blight susceptibility in transgenic pear plants overexpressing a pea ferritin gene. Plant Science, 180(5): 694-701.

Donnini, S., Castagna, A., Ranieri, A., Zocchi, G. (2009). Differential responses in pear and quince genotypes induced by Fe deficiency and bicarbonate. Journal of Plant Physiology, 166(11): 1181-1193.

Eichert, T., Peguero-Pina, J. J., Gil-Pelegrín, E., Heredia, A., Fernández, V. (2010). Effects of iron chlorosis and iron resupply on leaf xylem architecture, water relations, gas exchange and stomatal performance of field-grown peach (Prunus persica). Physiologia Plantarum, 138(1): 48-59.

Fernández, V., Eichert, T., Del Río, V., López-Casado, G., Heredia-Guerrero, J. A., Abadía, A., Heredia, A., Abadía, J. (2008). Leaf structural changes associated with iron deficiency chlorosis in field-grown pear and peach: physiological implications. Plant and Soil, 311(1-2): 161.

Gao, C., Wang, Y., Xiao, D. S., Qiu, C. P., Han, D. G., Zhang, X. Z., Wu, T., Han, Z. H. (2011). Comparison of cadmium-induced irondeficiency responses and genuine iron-deficiency responses in Malus xiaojinensis. Plant Science, 181(3): $269-274$.

Garcia, M. J., Corpas, F. J., Lucena, C., Alcantara, E., Perez-Vicente, R., Zamarreno, A. M., Bacaicoa, E., Garcia-Mina, J. M., Bauer, P., Romera, F. J. (2018). A shoot Fe signaling pathway requiring the OPT3 transporter controls GSNO reductase and ethylene in Arabidopsis thaliana roots. Frontiers in Plant Science, 9: 1325.

Gerardin, T., Douthe, C., Flexas, J., Brendel, O. (2018). Shade and drought growth conditions strongly impact dynamic responses of stomata to variations in irradiance in Nicotiana tabacum. Environmental and Experimental Botany, 153: 188-197.

Gruber, B., Kosegarten, H. (2002). Depressed growth of non-chlorotic vine grown in calcareous soil is an iron deficiency symptom prior to leaf chlorosis. Journal of Soil Science and Plant Nutrition, 165(1): 111-117.

Hoagland, D. R., Arnon, D. I. (1950). The water-culture method for growing plants without soil. Circular 347. Agricultural Experiment Station, University of California, Berkeley.

Jiménez, S., Ollat, N., Deborde, C., Maucourt, M., Rellán-Álvarez, R., Moreno, M. Á., Gogorcena, Y. (2011). Metabolic response in roots of Prunus rootstocks submitted to iron chlorosis. Journal of Plant Physiology, 168(5): 415-423.

Jiménez, S., Pinochet, J., Abadia, A., Moreno, M. Á., Gogorcena, Y. (2008). Tolerance response to iron chlorosis of Prunus selections as rootstocks. HortScience, 43(2): 304-309.

Junlin, L., Lei, H., Yanhua, S., Hongen, G., Huanchao, Z. (2019). Functional identification of Ammopiptanthus mongolicus anion channel AmSLAC1 involved in drought induced stomata closure. Plant Physiology and Biochemistry, 143: 340-350.

Kiani-Pouya, A., Rasouli, F., Rabbi, B., Falakboland, Z., Yong, M., Chen, Z. H., Zhou, M., Shabala, S. (2020). Stomatal traits as a determinant of superior salinity tolerance in wild barley. Journal of Plant Physiology, 245: 153108.

Kobayashi, T., Nishizawa N. K. (2012). Iron uptake, translocation, and regulation in higher plants. Annual Review of Plant Biology, 63: 131152.

Larbi, A., Abadía, A., Abadía, J., Morales, F. (2006). Down co-regulation of light absorption, photochemistry, and carboxylation in Fe-deficient plants growing in different environments. Photosynthesis Research, 89:113-126. 
Lawson, T., Matthews, J. (2020). Guard cell metabolism and stomatal function. Annual Review of Plant Biology, 71: 273-302.

Lutts, S., Kinet, J. M., Bouharmont, J. (1996). NaCl-induced Senescence in Leaves of Rice (Oryza sativa L.) Cultivars Differing in Salinity Resistance. Annals of Botany, 78: 389-398.

Mattiello, E. M., Ruiz, H. A., Neves, J. C., Ventrella, M. C., Araújo, W. L. (2015). Zinc deficiency affects physiological and anatomical characteristics in maize leaves. Journal of Plant Physiology, 183: 138-143.

Molassiotis, A., Tanou, G., Diamantidis, G., Patakas, A., Therios, I. (2006). Effects of 4-month Fe deficiency exposure on Fe reduction mechanism, photosynthetic gas exchange, chlorophyll fluorescence and antioxidant defense in two peach rootstocks differing in Fe deficiency tolerance. Journal of Plant Physiology, 163(2): 176-185.

Morales, F., Abadía, A., Abadía, J. (1990). Characterization of the xanthophyll cycle and other photosynthetic pigment changes induced by iron deficiency in sugar beet (Beta vulgaris L.). Plant Physiology, 94(2): 607-613.

Pouyafard, N., Akkuzu, E., Kaya, Ü. (2016). Kıyı Ege koşullarında yetiştirilen Ayvalık zeytin fidanlarında su stresine bağlı bazı fizyolojik ve morfolojik değişimlerin belirlenmesi. Journal of Tekirdag Agricultural Faculty, 13(1): 88-98.

Ridolfi, M., Garrec, J. P. (2000). Consequences of an excess Al and a deficiency in Ca and Mg for stomatal functioning and net carbon assimilation of beech leaves. Annals of Forest Science, 57(3): 209-218.

Romero-Romero, J. L., Inostroza-Blancheteau, C., Orellana, D., Aquea, F., Reyes-Díaz, M., Gil, P.M., Matte, J. P., Arce-Johnson, P. (2018). Stomata regulation by tissue-specific expression of the Citrus sinensis MYB61 transcription factor improves water-use efficiency in Arabidopsis. Plant Physiology and Biochemistry, 130: 54-60.

Sharma, P. N., Tripathi, A., Kumar, N., Gupta, S., Kumar, P., Chatterjee, J., Tewari, R. K. (2016). Iron plays a critical role in stomatal closure in cauliflower. Environmental and Experimental Botany, 131: 68-76.

Shi, P., Li, B., Chen, H., Song, C., Meng J., Xi, Z., Zhang, Z. (2017). Iron supply affects anthocyanin content and related gene expression in berries of Vitis vinifera cv. Cabernet Sauvignon. Molecules, 22(2): 283.

Smart, R. E., Bingham, G. E. (1974). Rapid estimates of relative water content. Plant Physiology, 53: 258-260.

Solari, L. I., Johnson, S., DeJong, T. M. (2006). Hydraulic conductance characteristics of peach (Prunus persica) trees on different rootstocks are related to biomass production and distribution. Tree Physiology, 26(10): 1343-1350.

Stavrianakou, S., Liakopoulos, G., Karabourniotis, G. (2006). Boron deficiency effects on growth, photosynthesis and relative concentrations of phenolics of Dittrichia viscosa (Asteraceae). Environmental and Experimental Botany, 56(3): 293-300.

Tagliavini, M., Rombolà, A. D. (2001). Iron deficiency and chlorosis in orchard and vineyard ecosystems. European Journal of Agronomy, 15(2): 71-92.

Valipour, M., Baninasab, B., Khoshgoftarmanesh, A. H., Gholami, M. (2020). Oxidative stress and antioxidant responses to direct and bicarbonate-induced iron deficiency in two quince rootstocks. Scientia Horticulturae, 261: 108933.

Vráblová, M., Hronková, M., Vrábl, D., Kubásek, J., Šantrůček, J. (2018). Light intensity-regulated stomatal development in three generations of Lepidium sativum. Environmental and Experimental Botany, 156: 316-324.

Yin, R., Bai, T., Ma, F., Wang, X., Li, Y., Yue, Z. (2010). Physiological responses and relative tolerance by Chinese apple rootstocks to NaCl stress. Scientia Horticulturae, 126(2): 247-252.

Zhu, K., Yuan, F., Wang, A., Yang, H., Guan, D., Jin, C., Zhang, H., Zhang, Y., Wu, J. (2019). Effects of soil rewatering on mesophyll and stomatal conductance and the associated mechanisms involving leaf anatomy and some physiological activities in Manchurian ash and Mongolian oak in the Changbai Mountains. Plant Physiology and Biochemistry, 144: 22-34 